\title{
KORELASI ANTARA STRATEGI NILAI-NILAI PENDIDIKAN KARAKTER RELIGIUS DENGAN TERBENTUKNYA AKHLAQ DALAM DIRI SISWA
}

\author{
Ahmad Afghor Fahruddin \\ Sekolah Tinggi Agama Islam Daruttaqwa Suci Gresik, Indonesia \\ Email: aaf_evol@yahoo.com \\ Moh. Syamsi \\ Sekolah Tinggi Agama Islam Daruttaqwa Suci Gresik, Indonesia \\ Email: mohsyamsi@staidagresik.ac.id
}

\begin{abstract}
This paper will discuss the relationship between the values of religious character education strategies with the formation of morality in students. The type and approach in this research uses descriptive qualitative. In the current era of globalization, people ranging from adolescents, adults and even the elderly and most importantly to parents must be prepared to receive positive and negative impacts in the times, because we can access various information both nationally and internationally very young and fast. To deal with all this, the world of education prioritizes in terms of what strategies can instill the values of religious character education that focus on the formation of morality in students. In implementing the strategy of religious character education values the principal must apply important points such as strategy, educational values, religious character and morality.
\end{abstract}

Keywords: Strategy, Educational Values, Religious Character, Morals

\begin{abstract}
Abstrak: Tulisan ini akan membahas tentang hubungannya antara strategi nilai-nilai pendidikan karakter religius dengan terbentuknya akhlaq dalam diri siswa. Jenis dan pendekatan dalam penelitian ini menggunakan kualitatif deskriptif. Zaman di era globalisasi saat ini, masyarakat mulai dari kalangan remaja, dewasa bahkan usia lanjut serta yang paling utama kepada orang tua harus siap untuk menerima dampak positif dan negative dalam perkembangan zaman, karena berbagai informasi baik nasional sampai internasional bisa kita akses dengan sangat muda dan cepat. Untuk menghadapi semua ini dunia pendidikan lebih memprioritaskan dalam hal strategi apa yang bisa menanamkan nilai-nilai pendidikan karakter religius yang berfokus dalam terbentuknya akhlaq dalam diri siswa. Di dalam penerapan strategi nilai-nilai pendidikan karakter religius kepala sekolah harus menerapkan poin-poin penting seperti strategi, nilai-nilai pendidikan, karakter religius dan Akhlaq.

Kata Kunci: Strategi, Nilai-Nilai Pendidikan, Karakter Religius, Akhlaq
\end{abstract}




\section{Pendahuluan}

Sekarang telah memasuki zaman era globalisasi, dimana semua informasi di dunia ini bisa diakses hanya dalam waktu sekejap saja, namun kecanggihan yang dihadapi oleh masyarakat saat ini mulai dari kalangan remaja sampai kalangan dewasa bahkan usia lanjut, tentu semua itu akan membawa dampak positif dan negatif.

Akhir-akhir ini dalam dunia pendidikan lebih di prioritaskan, ditekankan dalam hal pendidikan karakter. Semua itu tidak luput karena keprihatinan timbulnya kenakalan generasi jaman sekarang, sering kita jumpai dalam kehidupan sehari-hari, banyaknya kejahatan, tawuran, seks bebas, kekerasan pada anak dan wanita, menggunakan obat-obatan terlarang, anak kurang hormat kepada orang tua, bahkan saat ini sering kita mendapatkan informasi dalam media berita baik itu melalui media koran, majalah atau televisi sering terjadinya penindakan kriminal dalam hal anak membunuh orang tua, murid membunuh gurunya padahal penyebabnya hanya masalah sepilih, dan Ironisnya para pelaku tidak hanya yang berpendidikan rendah, tapi orang yang berpendidikan tinggipun ada yang melakukan yang bisa merugikan negara seperti yang dilakukan oleh para pejabat yaitu korupsi yang latar belakang pendidikannya adalah perguruan tinggi. Semua itu disebabkan terjadinya kemerosotan moral karena hilangnya nilai-nilai pendidikan karakter dari para pemuda generasi bangsa.

Masalah pendidikan karakter merupakan salah satu problema yang selalu menjadi perhatian setiap bangsa, baik dalam sebuah negara yang telah maju maupun negara yang sedang berkembang.

Hilangnya nilai pendidikan karakter pada remaja, tentu menjadi tantangan serius bagi pendidikan, sebagai lembaga yang memiliki peran penting dalam terwujudnya generasi bangsa kebanggaan. Tertuang dalam UU No 20 tahun 2003 tentang sistem pendidikan nasional pada pasal 3 yang menyebutkan bahwa: pendidikan nasional berfungsi untuk mengembangkan, membentuk karakter dan peradaban bangsa yang bermartabat dalam rangka mencerdaskan kehidupan bangsa. Pendidikan nasional bertujuan untuk melihat perkembangan potensi peserta didik agar menjadi manusia yang beriman, berakhlak mulia, sehat, berilmu, kreatif, mandiri dan menjadi warga negara yang demokratis serta bertanggung jawab.

Bisa jadi penyebab terjadinya tindakan-tindakan tercela dipicu oleh lingkungan sosial, fanatisme yang kebablasan, dan situasi keluarga yang ketat juga meyebabkan pelajar menempuh jalan pintas dalam mengekspresikan emosi mereka dengan cara bertengkar dan melakukan kekerasan fisik. Selain itu pengaruh televisi yang selalu disuguhkan dengan tayangan-tayangan kekerasan juga memiliki kontribusi terhadap munculnya sikap anarkisme pada anak. ${ }^{2}$

Pendidikan Karakter dalam Islam menjadi salah satu jawaban yang tepat atas permasalahan-permasalahan yang telah terjadi diatas, untuk itu kita harus mengetahui nilainilai pendidikan karakter religius dan strategi nilai-nilai pendidikan karakter religius. Sehingga bisa tercipta kepribadian manusia yang berakhlaq.

Metode Penelitian ini menggunakan pendekatan deskriftif kualitatif. Penelitian kualitatif mendeskripsikan kejadian atau fenomena tentang korelasi antara strategi nilai-nilai pendidikan karakter religious dengan terbentuknya akhlaq dalam diri siswa. Teknik pengumpulan data menggunakan studi wawancara bersama kepala sekolah, wakil kepala sekolah bidang kurikulum, kesiswaan, dan stake holder internal lainnya, studi dokumentasi

\footnotetext{
${ }^{1}$ Undang-Undang Sistem Pendidikan Nasional No 20 Tahun 2003.

${ }^{2}$ Rusydi Sulaiman, Nilai-Nilai Karakter Islam : Berhulu dari Akhlak, berhilir pada Rakhmat, (Bandung : Marja, 2013), Hlm. 156
} 
yaitu mengkopi dan menganalisis dokumen yang berkaitan dengan standar di sekolah dan studi observasi kaitannya dengan suasana akademik sekolah, belajar mengajar dan kegiatan ekstrakulikuler sebagai penunjang. Jika di tinjau dari segi tempat penelitian, maka penelitian ini termasuk penelitian lapangan (field Research), yaitu penelitian yang langsung dilakukan dilapangan terhadap responden internal sekolah. Instrumen kunci dalam penelitian kualitatif adalah peneliti itu sendiri. Peneliti mengumpulkan sendiri data yang diperoleh dari wawancara, observasi, dan studi dokumen. Namun demikian, peneliti menggunakan pedoman dari masing-masing teknik pengumpulan data. Analisis data kualitatif yang digunakan pada penelitian ini yaitu mengacu kepada model interaktif.

\section{Strategi}

Strategi bisa diartikan perencanaan yang berisi tentang proses kegiatan yang didesain untuk mencapai tujuan pendidikan tertentu.

Ada dua hal yang perlu di cermati dari pengertian diatas yaitu:

1. Strategi merupakan rangkaian kegitan termasuk penerapan metode dan pemanfaatan berbagai sumber daya/kekuatan. Hal ini berarti penyusunan suatu strategi baru sampai pada proses penyusunan rencana kerja belum sampi tindakan.

2. Strategi disusun untuk mencapai tujuan tetentu. Artinya arah dari semua keputusan penyusunan strategi adalah pencapaian tujuan. Dengan demikian, penyusunan langkahlangkah, pemanfaatan berbagai macam fasilitas dan sumber belajar semuanya diarahkan dalam upaya pencapaian tujuan. Oleh sebab itu, sebelum menentukan strategi, perlu dirumuskan tujuan yang jelas yang dapat diukur keberhasilannya, sebab tujuan adalah rohnya dalam Implementasi suatu strategi. ${ }^{3}$

\section{Nilai-Nilai pendidikan}

Pendidikan Karakter dilakukan melalui pendidikan nilai-nilai atau kebajikan yang menjadi nilai dasar karakter bangsa. Oleh karena itu, pendidikan karakter pada dasarnya adalah pengembangan nilai-nilai yang berasal dari pandangan hidup, ideologi bangsa, agama, budaya, dan nilai-nilai yang merumuskan dalam tujuan pendidikan Nasional. ${ }^{4}$

Nilai-nilai yang telah dikembangkan dalam pendidikan karakter yang ada di Indonesia diidentifikasikan berasal dari 4 sumber.

1. Agama. Dimana masyarakat indonesia adalah masyarakat yang beragama. Oleh karena itu dalam kehidupan individu, masyarakat, serta bangsa selalu didasari pada ajaran agama dan kepercayaannya. Begitu juga secara politis, kehidupan kenegaraan pun didasari pada nilainilai yang berasal dari agama.

2. Pancasila. Nilai-nilai yang terkandung dalam pancasila menjadi nilai-nilai yang mengatur pada kehidupan di dalam politik, hukum, ekonomi, kemasyarakatan, budaya dan seni. Pada dasarnya pendidikan budaya dan karakter bangsa bertujuan untuk mempersiapkan peserta didik menjadi warga negara yang lebih baik, yaitu warga negara yang memiliki kemampuan, dan menerapkan nilai-nilai pancasila dalam kehidupannya.

3. Budaya. Nilai Budaya ini dijadikan dasar dalam pemberian makna terhadap suatu tatanan serta arti dalam komunikasi antara anggota masyarakat tersebut. posisi budaya yang

\footnotetext{
${ }^{3}$ Wina Sanjaya, Strategi Pembelajaran Berorientasi Standar Proses Pendidikan (Jakarta: Kencana, 2008), 125.

${ }^{4}$ Zubaedi, Desain Pendidikan Karakter dan Aplikasinya dalam Lembaga Pendidikan, (Jakarta: Kencana, 2011), h. $72-73$
} 
mempunyai peran sangat penting dalam kehidupan masyarakat dan menjadi sumber nilai dalam pendidikan budaya dan karakter bangsa. ${ }^{5}$

4. Tujuan Pendidikan Nasional. UU RI No. 20 Tahun 2003 tentang Sistem Pendidikan Nasional merumuskan kegunaan dan tujuan pendidikan Nasional yang digunakan dalam mengembangkan upaya pendidikan di Indonesia. Pasal 3 UU Sisdiknas menyebutkan, "pendidikan Nasional berfungsi mengembangkan dan membentuk pola pikir serta peradaban bangsa yang bermartabat dalam rangka mencerdaskan kehidupan bangsa, bertujuan untuk berkembang untuk potensi peserta didik agar menjadi manusia yang beriman dan bertakwa kepada Tuhan YME, berakhlak mulia, sehat, berilmu, cakap, kreatif, mandiri, dan menjadi warga negara yang demokratis dan bertanggung jawab.

Berdasarkan kajian nilai-nilai agama, norma-norma sosial, hukum, etika akademik dan prinsip-prinsip HAM telah teridentifikasi butir-butir nilai yang dikelompokkan menjadi 5 nilai yang paling utama yaitu mulai dari nilai-nilai perilaku manusia dalam hubungan dengan Tuhan YME, diri sendiri, sesama manusia serta lingkungan serta kebangsaan. Adapun daftar nilai-nilai utama yang dimaksud dan deskripsi ringannya. ${ }^{6}$

1. Nilai Karakter dalam hubungannya dengan Tuhan (Religius, Watak, ucapan, dan prilaku seseorang yang selalu berdasarkan pada nilai ketuhanan)

2. Nilai karakter dalam hubungannya dengan diri sendiri
a. Jujur
b. Bertanggung jawab
c. Bergaya hidup sehat
d. Disiplin
e. Kerja keras
f. Percaya diri
g. Berjiwa Wirausaha
h. Berfikir logis, kritis, kreatif dan inovatif
i. Mandiri
j. Ingin tahu
k. Cinta ilmu

3. Nilai karakter dalam hubungannya dengan sesame
a. Sadar akan hak dan kewajiban diri dan orang lain
b. Patuh pada norma sosial
c. Menghargai karya dan prestasi orang lain
d. Santun
e. Demokratis

4. Nilai karakter dalam hubungannya dengan lingkungan (Peduli sosial dan lingkungan)

5. Nilai kebangsaan (Nasionalis, Menghargai keberagaman)

Menurut Megawangi Nilai-nilai pendidikan Karakter dapat dibangun dengan 3 tahap antara lain :

1. Moral Knowing: memahamkan dengan baik pada anak tentang arti keabaikan. Mengapa harus berperilaku baik dan apa manfaat berperilaku baik.

2. Moral Feeling: aspek yang lain yang harus ditanamkan kepada anak yang merupakan sumber energi dari diri manusia untuk bertindak sesuai dengan prinsip-prinsip moral.

\footnotetext{
${ }^{5}$ Syamsul Kurniawan, Pendidikan Karakter : Konsepsi dan Implementasinya di Lingkungan Keluarga, Sekolah, Perguruan Tinggi, dan Masyarakat, (Depok : Arr-Ruzz Media, 2013), h. 39-40

${ }^{6}$ M. Mahbubi, Pendidikan Karakter :Implementasi Aswaja sebagai Nilai Pendidikan Karakter, h. 44-48
} 
3. Moral Action: bagaimana membuat pengetahuan moral dapat diwujudkan menjadi tindakan nyata. Perbuatan tindakan moral ini merupakan hasil (outcome) dari dua komponen karakter lainya.

Adapun nilai Karakter yang tertanam/diharapkan menurut undang-undang RI no.17 tahun 2007 tentang RPPJN 2015-2025 adalah: kompetitif, berakhlak mulia, bermoral, bertoleran, bergotong royong, patriotik, berbudaya dan berorientasi IPTEK berdasarkan pancasila dan dijiwai oleh iman dan Takwa kepada Tuhan YME. ${ }^{7}$

Sedangkan pada tahun 2010, ${ }^{8}$ Departemen Pendidikan Nasional yang sekarang menjadi kementrian pendidikan dan kebudayaan (KEMENDIKBUD) mencanangkan 18 nilai pendidikan Karakter yang harus diajarkan melalui pembelajaran langsung di kelas.

Berikut adalah ke-18 nilai pendidikan Karakter dimaksud dengan segala uraian dan sejenisnya. Nilai-nilai pendidikan Karakter tersebut adalah sebagai berikut : ${ }^{9}$

\section{Tabel: 1}

Nilai-Nilai Karakter Bangsa

\begin{tabular}{|c|c|}
\hline NILAI & DESKRIPSI \\
\hline 1. Religius & $\begin{array}{l}\text { Sikap dan perilaku yang patuh dalam melaksanakan ajaran } \\
\text { agama yang dianutnya, toleran terhadap pelaksanaan ibadah } \\
\text { agama lain, dan hidup rukun dengan pemeluk agama lain. }\end{array}$ \\
\hline 2. Jujur & $\begin{array}{l}\text { Perilaku yang didasarkan pada upaya menjadikan dirinya } \\
\text { sebagai orang yang selalu dapat dipercaya dalam perkataan, } \\
\text { tindakan, dan pekerjaan. }\end{array}$ \\
\hline 3. Toleransi & $\begin{array}{l}\text { Sikap dan tindakan yang menghargai perbedaan agama, suku, } \\
\text { etnis, pendapat, sikap, dan tindakan orang lain yang berbeda } \\
\text { dari dirinya. }\end{array}$ \\
\hline 4. Disiplin & $\begin{array}{l}\text { Tindakan yang menunjukkan perilaku tertib dan patuh pada } \\
\text { berbagai ketentuan dan peraturan. }\end{array}$ \\
\hline 5. Kerja Keras & $\begin{array}{l}\text { Perilaku yang menunjukkan upaya sungguh-sungguh dalam } \\
\text { mengatasi berbagai hambatan belajar dan tugas, serta } \\
\text { menyelesaikan tugas dengan sebaik-baiknya. }\end{array}$ \\
\hline 6. Kreatif & $\begin{array}{l}\text { Berpikir dan melakukan sesuatu untuk menghasilkan cara atau } \\
\text { hasil baru dari sesuatu yang telah dimiliki. }\end{array}$ \\
\hline 7. Mandiri & $\begin{array}{l}\text { Sikap dan perilaku yang tidak mudah tergantung pada orang } \\
\text { lain dalam menyelesaikan tugas-tugas. }\end{array}$ \\
\hline 8. Demokratis & $\begin{array}{l}\text { Cara berfikir, bersikap, dan bertindak yang menilai sama hak } \\
\text { dan kewajiban dirinya dan orang lain. }\end{array}$ \\
\hline 9. Rasa Ingin Tahu & $\begin{array}{l}\text { Sikap dan tindakan yang selalu berupaya untuk mengetahui } \\
\text { lebih mendalam dan meluas dari sesuatu yang dipelajarinya, } \\
\text { dilihat, dan didengar. }\end{array}$ \\
\hline 10. Semangat Kebangsaan & $\begin{array}{l}\text { Cara berpikir, bertindak, dan berwawasan yang menempatkan } \\
\text { kepentingan bangsa dan negara di atas kepentingan diri dan } \\
\text { kelompoknya. }\end{array}$ \\
\hline
\end{tabular}

\footnotetext{
${ }^{7}$ Ibid., h.12

${ }^{8}$ Akh Muzakki, Instrumen Nilai dalam Pembelajaran :Perspektif Sosiologi Pendidikan Karakter, h. 89

${ }^{9}$ Kementerian Pendidikan Nasional, 2010, Pengembangan Pendidikan Budaya dan Karakter Bangsa Pedoman Sekolah, Jakarta: Badan Penelitian dan Pengembangan
} 


\begin{tabular}{|l|l|}
\hline 11. Cinta Tanah Air & $\begin{array}{l}\text { Cara berfikir, bersikap, dan berbuat yang menunjukkan } \\
\text { kesetiaan, kepedulian, dan penghargaan yang tinggi terhadap } \\
\text { bahasa, lingkungan fisik, sosial, budaya, ekonomi, dan politik } \\
\text { bangsa. }\end{array}$ \\
\hline 12. Menghargai Prestasi & $\begin{array}{l}\text { Sikap dan tindakan yang mendorong dirinya untuk } \\
\text { menghasilkan sesuatu yang berguna bagi masyarakat, dan } \\
\text { mengakui, serta menghormati keberhasilan orang lain. }\end{array}$ \\
\hline $\begin{array}{l}\text { 13. Bersahabat/ } \\
\text { Komuniktif }\end{array}$ & $\begin{array}{l}\text { Tindakan yang memperlihatkan rasa senang berbicara, bergaul, } \\
\text { dan bekerja sama dengan orang lain. }\end{array}$ \\
\hline 14. Cinta Damai & $\begin{array}{l}\text { Sikap, perkataan, dan tindakan yang menyebabkan orang lain } \\
\text { merasa senang dan aman atas kehadiran dirinya. }\end{array}$ \\
\hline 15. Gemar Membaca & $\begin{array}{l}\text { Kebiasan menyediakan waktu untuk membaca berbagai } \\
\text { bacaan yang memberikan kebajikan bagi dirinya. }\end{array}$ \\
\hline 16. Peduli Lingkungan & $\begin{array}{l}\text { Sikap dan tindakan yang selalu berupaya mencegah kerusakan } \\
\text { pada lingkungan alam di sekitarnya, dan mengembangkan } \\
\text { upaya-upaya untuk memperbaiki kerusakan alam yang sudah } \\
\text { terjadi. }\end{array}$ \\
\hline 17. Peduli Sosial & $\begin{array}{l}\text { Sikap dan tindakan yang selalu ingin memberi bantuan pada } \\
\text { orang lain dan masyarakat yang membutuhkan. }\end{array}$ \\
\hline 18. Tanggung-jawab & $\begin{array}{l}\text { Sikap dan perilaku seseorang untuk melaksanakan tugas dan } \\
\text { kewajibannya, yang seharusnya dia lakukan, terhadap diri } \\
\text { sendiri, masyarakat, lingkungan (alam, sosial dan budaya), } \\
\text { negara dan Tuhan Yang Maha Esa. }\end{array}$ \\
\hline
\end{tabular}

\section{Karakter Religius}

\section{Pengertian Karekter Religius.}

Karakter religius secara umum diartikan sebagai sikap atau perilaku yang patuh dalam melaksanakan ajaran agama yang di anutnya, toleran terhadap pelaksanaan ibadah, dan hidup rukun dengan sesama. ${ }^{10}$

Karakter mengalami pertumbuhan menjadi sebuah watak yang dapat diandalkan untuk merespon dengan cara bermoral. Maka dari itu kartakter memiliki tiga macam yang saling berkaitan diantaranya adalah perilaku moral, perasaan, dan pengetahuan. Sedangkan religius adalah perilaku dan sikap yang patuh dalam melakukan ajaran agama, toleransi, rukun sesame agama lain."

Karakter religius dapat disimpulkan yaitu pendekatan seseorang kepada Allah SWT, dengan melandasi perilaku dan sikap sebagai wujud pendekatan kepada Allah SWT. ${ }^{12}$

\section{Nilai-nilai Karakter Religius.}

Nilai karakter dalam kurikulum salah satunya adalah karakter religius. Nilai religius adalah perilaku yang patuh dalam menjalankan agama, toleran dan rukun dengan agama lain. Seseorang dapat di sebut religius ketika selalu mendekatkan diri kepada Allah SWT. ${ }^{13}$

Nilai- nilai religius diantarnya adalah: ${ }^{14}$

\footnotetext{
${ }^{10}$ Wibowo, Agus, Pendidikan Karakter, (Jakarta: Pustaka Pelajar, 2012), hal. 26-27

${ }^{1 l}$ Chusnul Maesaroh, "Manajemen Kurikulum Takhasus Untuk Mengembangkan Karakter Religius Siswa di SD HJ. Isriati Baiturrahman 2".Skripsi. Semarang: Fakultas Ilmu Tarbiah dan Keguruan Universutas Islam Negeri Walisongo. 2015, hal. 29.

12 Ibid.hal. 30

${ }^{13}$ Kurniawan, Syamsul, "Pedidikan Karakter Konsep dan Implementasinya Secara Terpadu di Lingkungan Keluarga, Sekolah, Perguruan Tinggi dan Masyarakat”, (Yogyakarta: Ar-Ruzz Media, 2014, hal. 127.
} 
a. Mengamalkan ibadah diantaranya adalah sholat.

b. Membaca al-Quran ataupun juga hafalan.

c. Menghormati ketua orang tua, guru dan lainnya

d. Menjalin silahturohmi.

e. Sabar.

Dalam membentuk karakter religius yang baik harus adanya komitmen beragama yang kuat sebagai seorang muslim, siswa diharapkan dapat memiliki religius yang baik dengan cara melaksanakan rutinitas keagamaan disekolah maupun di rumah tidak hanya mematuhi peraturan.

Proses pembelajaran yang seharusnya dilakukan guru dalam proses pembelajaran pendidikan karakter religius adalah sebagai berikut: ${ }^{15}$

a. Dalam pelajaran harus di kaitkan dengan kehidupan anak yang ada kaitannya dengan sekitar apa yang berlaku dalam lingkungan kehidupan.

b. Memperluas kegiatan keagamaan diluar ruang belajar.

c. Pendidikan seharusnya dilakukan melalui keteladanan oleh pendidik.

d. Menceritakan kisah-kisah tokoh agama untuk mengajarkan kebaikan dan kemuliaan dalam perjuangan hidup.

e. Membiasakan praktek ibadah di sekolah.

f. Mewujudkan suasana kasih sayang dan hubungan harmonis antara guru dan murid.

Menurut Imam Al-Ghazali Dalam Risalah Ayyuha alWalad mengenai prinsip pendidikan karakter yaitu menekankan pada pentingnya nilai akhlak yang mengarah pada prinsip integrasi spiritual dalam tujuan pendidikan karakter. Al-Ghazali menganggap bahwa pembentukan karakter lebih dekat dengan akhlak, yaitu spontan manusia dalam menentukan tingkah laku, atau melakukan perbuatan yang telah menyatu dalam diri manusi sehingga ketika muncul tidak perlu di fikirkan lagi. Apa yang dikatakan Al-Ghazali tersebut merupakan karakter yang telah mengakar dalam diri seseorang. ${ }^{16}$

\section{Akhlaq}

Akhlak secara etimologi berasal dari kata khuluq dan jamanya akhlāq yang berarti budi pekerti, etika, moral. Demikian pula kata khuluq mempunyai kesesuaian dengan khilq, hanya saja khuluq merupakan perangai manusia dari dalam diri (ruhaniah) sedang khilq merupakan perangai manusia dari luar (jasmani). ${ }^{17}$

Ibnu Maskawaih dalam bukunya Tahdzīb al-Akhlāq wa Thathīr al-Arāq mendefinisikan akhlak dengan keadaan gerak yang mendorong ke arah melakukan perbuatan dengan tidak memerlukan pikiran. ${ }^{18}$ Menurut Ahmad Amin, yang disebut akhlak ialah kehendak yang dibiasakan. Artinya, bila membiasakan sesuatu, maka kebiasaan itulah yang dinamakan akhlak. Dalam penjelasan beliau, kehendak ialah ketentuan dari beberapa keinginan sesudah bimbang, sedangkan kebiasaan ialah perbuatan yang diulang-ulang sehingga mudah dikerjakan. Jika kehendak itu dikerjakan berulang-kali sehingga menjadi kebiasaan, maka

\footnotetext{
${ }^{14}$ Syamsul Yusuf dan Nani M. Sugandhi, "Perkembangan Peserta Didik", (Jakarta: PT Raja Grafindo Persada, 2013), hal. 104.

${ }^{15}$ Nasrudin Aziz, Muhammad, "Model Pembelajaran Afektif Pendidikan Agama Islam Dalam Penanaman Karakter di MI Pesantren Anak Soleh (PAS) Baitul Quran Gontor Mlarak Ponorogo".Skripsi. Ponorogo: Fakultas Agama Islam Universitas Muhammadiyah Ponorogo. 2017, hal. 15.

${ }^{16}$ Agus Setiawan, "Prinsip Pendidikan Karakter Dalam Islam; Studi Komparasi Pemikiran AlGhazali dan Burhanuddin Al-Zarnuji” Jurnal Dinamika Ilmu, Volume 14, No l Juni, (2014), hal.9

${ }^{17}$ Abdullah bin Abdil Hamid al-Atsari, Panduan Aqidah Lengkap (Bogor: Pustaka Ibnu Katsir, 2005) Hlm. 243

${ }^{18}$ Ibid,hlm 243
} 
itulah yang kemudian berproses menjadi akhlak. ${ }^{19}$ Akhlaq adalah keadaan jiwa seseorang yang mendorongnya untuk melakukan perbuatan tanpa terlebih dahulu melalui pemikiran dan pertimbangan. ${ }^{20}$ Imam Ghazali dalam kitabnya Ihyā` Ulūm al-dīn menyatakan bahwa akhlaq adalah gambaran tingkah laku dalam jiwa yang lahir dari perbuatan dengan mudah tanpa melalui pemikiran. ${ }^{2 l}$

Akhlak ada kaitanya dengan moral. Moral merupakan istilah tentang perilau atau akhlak yang diterapkan kepada manusia sebagai individu maupun sebagai makhluk sosial. Dalam pandangan Islam, pendidikan moral adalah salah satu di mana unsur-unsur fisik, spiritual dan psikologis dirangsang dan dipandu menuju tindakan yang baik dan benar. Unsur-unsur nyata dari pendidikan moral yang dengan orang dan jiwa dalam orang tersebut. Pandangan Islam tentang moralitas sosial yang ideal bertujuan untuk membangun Islam karakter, dan dimanifestasikan dalam sebuah komunitas yang harmonis individu dalam hati dipandu untuk berinteraksi hanya dan cara-cara yang mulia. ${ }^{22}$

Karakter dan akhlak tidak memiliki perbedaan yang signifikan. Keduannya didefinisikan suatu tindakan yang terjadi tanpa memerlukan sebuah pemikiran lagi karena sudah dapat disebut kebiasaan. ${ }^{23}$ Oleh karena itu pentingnya peran orang tua dalam membiasakan hal-hal baik dalam kehidupan sehari-hari.

Untuk menentukan baik dan buruknya akhlak seseorang maka ia harus berpegang teguh dengan al-quran dan sunnah nabi Muhammad SAW, karena hanya melalui kedua sumber inilah manusia dapat memahami bahwa sifat-sifat yang baik dan sifat-sifat yang buruk, ada beberapa aspek ruang lingkup pendidikan akhlak yaitu. ${ }^{24}$ :

a. Akhlaq kepada Allah SWT

Orang islam yang memiliki akidah yang benar dan kuat, berkewajiban untuk berakhlak baik kepada Allah SWT, dengan cara menjaga kemauannya dengan meluruskan ubudiah dasar tauhid, menaati perintah-Nya dan menjauhi larangan-Nya serta ikhlas beramal sholeh.

b. Akhlak kepada diri sendiri

Manusia yang telah diciptakan dalam sibghoh Allah SWT. Dalam potensi fitroh manusia berkewajiban menjaganya dengan cara memelihara kesucian lahir maupun batin.

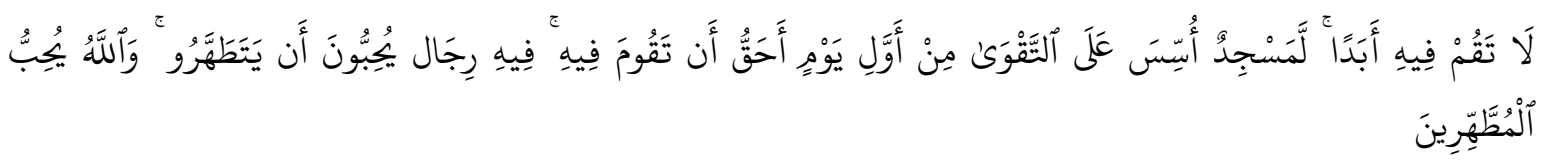

Artinya : "Janganlah kamu sembahyang di dalam masjid itu selama-lamanya. Sesungguhnya masjid yang didirikan atas dasar takwa (mesjid Quba), sejak hari pertama adalah lebih patut kamu bersembahyang di dalamnya. Di dalamnya ada orang-orang yang ingin membersihkan diri. Dan Allah menyukai orang-orangyang bersih." (QS At-taubah ayat 108)

c. Akhlak kepada keluarga

\footnotetext{
${ }^{19}$ Tim Dosen Agama Islam, Pendidikan Agama Islam Untuk Mahasiswa (Malang: IKIP Malang, 1995) Hlm. 170

20 Departemen Agama, Kurikulum dan Hasil Belajar Aqidah Akhlak Madrasah Tsanawiyah, (Jakarta: Departemen Agama, 2003), hlm. 151

${ }^{21}$ Ibid, hlm 152

${ }^{22}$ Mohammad Chowdhury, Emphasizing Morals, Values, And Character Education in Science Education And Science Teaching, dalam Mojes Journal: Journal of Ecational Science, Malaysia Online Journal, Vol. 4, Issue 2, 2016. hlm. 4

${ }^{23}$ Abdul Majid, Pendidikan Karakter Perspektif Islam, (Bandung; 201l, Remaja Rosdakarya), Hlm. 59

${ }^{24}$ Marzuki, Pendidikan Agama Islam, Yogyakarta : Ombak, 2012, hlm 181
} 
Akhlak kepada keluarga bisa dilakukan dengan cara berbakti kepada orang tua, bergaul dengan makfur, member nafkah sebaik mungkin.

d. Akhlak kepada tetangga

Membina tetangga sangat penting, sebab tetangga adalah sahabat yang paling dekat. Bahkan nabi Muhammad SAW dalam sabdanya menjelaskan bahwa "Tidak henti-hentinya jibril menyuruhku untuk berbuat baik kepada tetangga, hingga aku merasa tetangga sudah seperti ahli waris" (HR Bukhori)

e. Akhlak dalam kepemimpinan

Kita sebagai manusia harus siap menjadi pemimpin dan dipimpin kalau kita menjadi orang yang memimpin maka kita berkewajiban untuk memliki akhlak yang mulia karena kita akan menjadi teladan baik orang, kalau pun kita menjadi orang yang dipimpin maka kita harus patuh dan taat kepada pemimpin kita selama pemimpin kita tidak berbuat dzolim

f. Akhlak kepada lingkungan

Lingkungan yang dimaksud disini adalah segala sesuatu yang berada di sekitar manusia seperti hewan, tumbuh-tumbuhan dan benda mati.

Akhlak yang dikembangkan adalah cerminandari tugas kekholifahan di bumi yakni untuk menjaga agar setiap proses pertumbuhan alam dapat terus berjalan sesuai fungsi ciptaan-Nya.

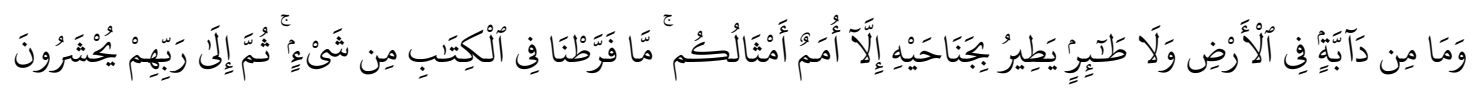

Artinya : "Dan tiadalah binatang-binatang yang ada di bumi dan burung-burung yang terbang dengan kedua sayapnya, melainkan umat-umat (juga) seperti kamu. Tiadalah Kami alpakan sesuatu pun di dalam Al Kitab, kemudian kepada Tuhanlah mereka dihimpunkan". (QS. Al-Anam ayat 38)

\section{Kesimpulan}

Zaman modern ini banyak sekali permasalahan yang melibatkan para kalangan remaja kita yang menimbulkan kenakalan generasi jaman sekarang, sering kita jumpai dalam kehidupan sehari-hari, banyaknya kejahatan, tawuran, seks bebas, kekerasan pada anak dan wanita, menggunakan obat-obatan terlarang, anak kurang hormat kepada orang tua. Dalam permasalahan ini dunia pendidikan sangat perlu untuk menerapkan strategi apa yang harus dilakukan dalam menerapkan nilai-nilai pendidikan karakter religius pada diri siswa untuk menanamkan kepribadian yang mempunyai akhlaq yang baik. Karena Nilai-nilai pendidikan terutama dalam karakter religius merupakan salah satu problema yang selalu menjadi perhatian setiap lembaga pendidikan, baik dalam lembaga pendidikan negeri maupun swasta, hilangnya nilai-nilai pendidikan terutama di karakter religius pada remaja, tentu menjadi tantangan serius bagi lembaga pendidikan.

Penerapan Nilai-nilai pendidikan terutama karakter religius menjadi salah satu jawaban yang tepat atas permasalahan-permasalahan yang terjadi di era modern ini, untuk itu kita harus menerapkan nilai-nilai pendidikan karakter religius dan strategi nilai-nilai pendidikan karakter religius di lembaga pendidikan. Dengan adanya penerapanya harapan kita bisa tercipta kepribadian manusia yang berakhlaq. 


\section{Daftar Pustaka}

Abdil Hamid al-Atsari, Abdullah bin, Panduan Aqidah Lengkap, (Bogor: Pustaka Ibnu Katsir, 2005)

Chowdhury, Mohammad, Emphasizing Morals, Values, Ethics, And Character Education in Science Education And Science Teaching, dalam Mojes Journal: Journal of Ecational Science, Malaysia Online Journal, Vol. 4, Issue 2, 2016

Departemen Agama, Kurikulum dan Hasil Belajar Aqidah Akhlak Madrasah Tsanawiyah, (Jakarta: Departemen Agama, 2003)

Kementerian Pendidikan Nasional, Pengembangan Pendidikan Budaya dan Karakter Bangsa Pedoman Sekolah, (Jakarta: Badan Penelitian dan Pengembangan, 2010)

Kurniawan, Syamsul, Pedidikan Karakter Konsep dan Implementasinya Secara Terpadu di Lingkungan Keluarga, Sekolah, Perguruan Tinggi dan Masyarakat, (Yogyakarta: Ar-Ruzz Media, 2014)

Majid, Abdul, Pendidikan Karakter Perspektif Islam, (Bandung: Remaja Rosdakarya, 2011)

Marzuki, Pendidikan Agama Islam, (Yogyakarta: Ombak, 2012)

Sanjaya, Wina, Strategi Pembelajaran Berorientasi Standar Proses Pendidikan, (Jakarta: Kencana, 2008)

Setiawan, Agus, Prinsip Pendidikan Karakter Dalam Islam; Studi Komparasi Pemikiran AlGhazali dan Burhanuddin Al-Zarnuji, Jurnal Dinamika Ilmu, Volume 14, No l Juni, 2014

Sulaiman, Rusydi, Nilai-Nilai Karakter Islam: Berhulu dari Akhlak, berhilir pada Rakhmat, (Bandung: Marja, 2013)

Tim Dosen Agama Islam, Pendidikan Agama Islam Untuk Mahasiswa, (Malang: IKIP Malang, 1995)

Undang-Undang Sistem Pendidikan Nasional No 20 Tahun 2003.

Wibowo, Agus, Pendidikan Karakter, (Jakarta: Pustaka Pelajar, 2012)

Yusuf, Syamsul dan Sugandhi, Nani M, Perkembangan Peserta Didik, (Jakarta: PT Raja Grafindo Persada, 2013)

Zubaedi, Desain Pendidikan Karakter dan Aplikasinya dalam Lembaga Pendidikan, (Jakarta: Kencana, 2011) 